\title{
TITLE IX AND OFFICIAL POLICY LIABILITY: MAXIMIZING THE LAW'S POTENTIAL TO HOLD EDUCATION INSTITUTIONS ACCOUNTABLE FOR THEIR RESPONSES TO SEXUAL MISCONDUCT
}

\author{
ERIN E. BUZUVIS* \\ Introduction
}

Title IX, the federal statute that prohibits sex discrimination in education, plays a key role in institutional accountability for sexual misconduct that is perpetrated by a school's students, faculty, and staff. ${ }^{1}$ The Supreme Court has confirmed that Title IX includes an implied right of action for money damages when the institution had actual notice that sexual harassment had occurred, or was likely to occur, and responded to that threat with deliberate indifference. ${ }^{2}$ But the deliberate indifference standard has proven to be a high and unpredictable bar for plaintiffs. For this reason, many institutions required the threat of government enforcement-issued in the form of the Department of Education's 2011 "Dear Colleague Letter"3 - to begin to address and improve their policies and practices for preventing and responding to sexual misconduct.

Recently, however, the Department of Education has incorporated the judicial deliberate indifference standard into its own regulations for enforcing Title IX. ${ }^{4}$ As a result, both judicial and administrative enforcement of Title IX may soon converge into the same generous standard that puts very little pressure on institutions to proactively or reactively respond to sexual misconduct on their campuses and in their communities. By responding only minimally to sexual misconduct, an institution can easily avoid committing deliberate indifference, while at the

* Professor of Law and Associate Dean for Academic Affairs, Western New England University School of Law.

1. See 20 U.S.C. $\S \S 1681-1688$ (2018).

2. See Gebser v. Lago Vista Indep. Sch. Dist., 524 U.S. 274, 281 (1998) (citing Cannon v. Univ. of Chi., 441 U.S. 677 (1979); Franklin v. Gwinnett Cty. Pub. Sch., 503 U.S. 60 (1992)).

3. Letter from Russlynn Ali, Assistant Sec'y for Civil Rights, U.S. Dep't of Educ. (Apr. 4, 2011), https://www2.ed.gov/about/offices/list/ocr/letters/colleague-201104.pdf [hereinafter Dear Colleague Letter].

4. See Nondiscrimination on the Basis of Sex in Education Programs or Activities Receiving Federal Financial Assistance, 85 Fed. Reg. 30026, 30045-46, 30574 (final rule published May 19, 2020, effective Aug. 14, 2020) (codified at 34 C.F.R. 106.44(a)). 
same time steering clear of the ever-present threat of litigation by respondents and individuals disciplined for sexual misconduct.

In light of this concern about unidirectional litigation pressure, this Article seeks to highlight a lesser-known Title IX theory of liability with the potential to promote institutional accountability for sexual misconduct: official policy liability. Simpson v. University of Colorado Boulder was the first case to recognize that educational institutions are liable under Title IX not only for indifferent response to the sexual misconduct of those under their control but also for sexual misconduct caused by their official policies. ${ }^{5}$ But this alternative theory of liability has not been widely utilized by plaintiffs' lawyers, and the majority of judicial decisions that have considered it have found it not to apply. ${ }^{6}$

Recently, however, two lower courts have countered this trend by denying motions to dismiss claims of official policy liability against both Baylor University ${ }^{7}$ and the University of Tennessee. ${ }^{8}$ In both cases, plaintiffs sought damages for sexual assault experienced at the hands of other students and claimed that their universities' official policies of indifference to sexual misconduct caused the assault. ${ }^{9}$

Part I of this Article provides background on Title IX and judicial enforcement under the more well-known deliberate indifference standard

5. See 500 F.3d 1170, 1182-85 (10th Cir. 2007); see also Wes R. McCart, Note, Simpson v. University of Colorado: Title IX Crashes the Party in College Athletic Recruiting, 58 DePaul L. REv. 153, 166 (2008) ("At the same time, the court's decision reinterpreted Title IX liability for sexual harassment by allowing for damages when the substantive violation is the proximate result of an educational institution's official policy. In doing so, the Tenth Circuit claims to have abandoned the Gebser and Davis precedent regarding actual notice standards in favor of the liability standard ....”) (footnotes omitted).

6. See infra Section III.D.1.

7. Doe 1 v. Baylor Univ., 240 F. Supp. 3d 646, 662 n.7 (W.D. Tex. 2017) (“Because the Court finds that Plaintiffs have met their burden under the official-policy rubric, it does not evaluate this category of claims under the actual notice and deliberate indifference framework articulated in Gebser and Davis.").

8. Doe v. Univ. of Tenn., 186 F. Supp. 3d 788, 804-08, 815-16 (M.D. Tenn. 2016). Specifically, in this case, the Middle District of Tennessee commented that it was not aware of any case before the Sixth Circuit where Title IX liability for thirdparty acts has been premised on an official policy of the funding recipient, rather than on actual knowledge and deliberate indifference to known acts of harassment, [yet] the court [found] that Gebser and Davis could support such a theory.

Id. at $804-05$.

9. Doe 1, 240 F. Supp. 3d at 653-56; Univ. of Tenn., 186 F. Supp. 3d at 791-92. 
developed in Gebser and Davis. Part II contrasts the standard of liability under deliberate indifference with that under official policy liability. Additionally, Part II traces the evolution of official policy liability from Simpson through the recent cases against Tennessee and Baylor. Finally, Part III explores the potential of official policy liability as a tool for maximizing Title IX's potential to promote institutional accountability, even in an era characterized by lax regulatory enforcement and litigious respondents.

\section{Institutional Liability Under Title IX}

Title IX is a federal civil rights statute that prohibits educational institutions that receive money from the federal government from discriminating on the basis of sex. ${ }^{10}$ While the statute was originally aimed at institutional policies that restricted women's access to graduate and professional school, modern judicial and regulatory interpretations have clarified that sexual harassment is a form of sex discrimination within the meaning of the law. ${ }^{11}$ Sexual assault is an obvious subset of sexual harassment because it is unwelcome and severe by definition, and because it often has the effect of interfering with a victim's educational opportunities. $^{12}$

\section{A. Title IX's Dual Enforcement Mechanisms}

Title IX's express statutory language contemplates administrative enforcement to ensure that federal funding does not flow to institutions that

10. 20 U.S.C. $\S 1681$ (a) (2018).

11. See, e.g., Gebser v. Lago Vista Indep. Sch. Dist., 524 U.S. 274, 281 (1998); Meritor Savings Bank v. Vinson, 477 U.S. 57, 64-67 (1986) (ruling under Title VII that unwelcome sexual advances, when sufficiently severe or pervasive to render a workplace environment hostile to members of one sex); Alexander v. Yale Univ., 459 F. Supp. 1, 4 (D. Conn. 1977) ("[A]cademic advancement conditioned upon submission to sexual demands constitutes [a claim of] sex discrimination in education ....."), aff'd, 631 F.2d 178, 186 (2d Cir. 1980); see also 29 C.F.R. § 1604.11(a) (1985) (including "unwelcome sexual advances" as actionable harassment on the basis of sex under Title VII).

12. See Jennings v. Univ. of N.C., 444 F.3d 255, 274 n.12 (4th Cir. 2006) (acknowledging that a single incident of sexual assault or rape could be sufficient to raise a jury question about whether a hostile environment exists); Soper v. Hoben, 195 F.3d 845, 854-55 (6th Cir. 1999) (explaining that rape and sexual abuse "obviously qualif[y] as . . . severe, pervasive, and objectively offensive sexual harassment that could deprive [the student] of access to the educational opportunities provided by her school"). 
discriminate on the basis of sex. ${ }^{13}$ Though every federal agency that administers federal funding to educational institutions is responsible for ensuring taxpayer dollars are not used to subsidize discrimination, the Department of Education (the "Department") is the exemplar enforcement agency. ${ }^{14}$ The Department investigates complaints of noncompliance and conducts comprehensive investigations at its own initiative. ${ }^{15}$ When the Department determines that an institution has not complied with Title IX, as interpreted by its implementing regulations and interpretive policies and guidance, it gives institutions the opportunity to correct noncompliant policies and practices, thereby avoiding penalties. ${ }^{16}$ Only institutions that fail to resolve compliance issues voluntarily risk losing their funding, which occurs only after a formal hearing. ${ }^{17}$ To date, however, the government has never withdrawn federal funding from an educational institution over issues of Title IX compliance. ${ }^{18}$

In addition, the Supreme Court has confirmed that Congress intended an implied private right of action that allows private litigants to supplement administrative enforcement in an effort to ensure Title IX accountability for educational institutions. ${ }^{19}$ This right of action allows plaintiffs to recover money damages ${ }^{20}$ or to attain injunctive relief. ${ }^{21}$ But as a matter of fairness

13. See 20 U.S.C. $\S 1682(a)$.

14. See Nondiscrimination on the Basis of Sex in Education Programs or Activities Receiving Federal Financial Assistance; Final Common Rule, 65 Fed. Reg. 52857, 52859 (Aug. 30, 2000) ("As set forth in this common rule, the substantive nondiscrimination obligations of recipients, for the most part, are identical to those established by the Department of Education ("ED") under Title IX."); see also Title IX and Sex Discrimination, U.S. DEP'T OF EDUC. (rev. Apr. 2015), https://www2.ed.gov/about/offices/list/ocr/ docs/tix_dis.html (noting that the Office for Civil Rights (a component of the U.S. Department of Education) enforces Title IX).

15. 34 C.F.R. $\S 100.7$ (c) (2020).

16. 34 C.F.R. $\S 106.71$ (incorporating 34 C.F.R. $\S \S 100.7,100.8$ ).

17. Id. (incorporating 34 C.F.R. $\S \S 100.8,100.9$ ).

18. In the early days of Title IX enforcement, some institutions resisted efforts of the Department of Education's predecessor agency, the Department of Health, Education \& Wellness, to apply Title IX beyond the specific program that had directly received the aid. See Erin E. Buzuvis, Title IX and Procedural Fairness: Why Disciplined-Student Litigation Does Not Undermine the Role of Title IX in Campus Sexual Assault, 78 MonT. L. REv. 71, 79 n.37 (2017). However, these institutions successfully invoked judicial review of agency action in order to avoid funding withdrawal, though these judicial decisions have been abrogated by subsequent amendments to Title IX. See id.

19. Cannon v. Univ. of Chi., 441 U.S. 677, 705-09 (1979).

20. Franklin v. Gwinnett Cty. Pub. Sch., 503 U.S. 60, 75-76 (1992).

21. Gebser v. Lago Vista Indep. Sch. Dist., 524 U.S. 274, 285-86 (1998). 
to educational institutions, the Supreme Court has held that schools may only be liable for their own intentional and unlawful conduct. ${ }^{22}$

Moreover, courts cannot force institutions to pay damages on a theory of vicarious liability or for accidental harm because Title IX is, at its core, a spending statute. ${ }^{23}$ Title IX is essentially a bilateral agreement between educational institutions and the federal government. According to that agreement, the federal government agrees to provide funding, and the recipients agree to the government's terms and conditions-including the condition not to engage in sex discrimination. ${ }^{24}$

As between these two parties, the remedy for breach, then, is the withdrawal of federal funds. Educational institutions arguably lack notice of the fact that, by accepting federal funding from the government, they could be liable to a "third party" such as a student or employee who experiences sex discrimination in violation of Title IX. ${ }^{25}$ But regulatory enforcement of Title IX raises no such concern because notice is built into the enforcement process. If an institution is ignorant of its obligation to comply with Title IX, it will receive an opportunity to correct its actions before losing any federal funds. ${ }^{26}$

Similarly, judicially imposed injunctions only apply on a prospective basis and, therefore, avoid notice concerns. But with regard to money damages, the Supreme Court has insisted that only an institution's intentional misconduct can give rise to such liability because, unlike

22. Davis v. Monroe Cty. Bd. of Educ., 526 U.S. 629, 642-43 (1999); Gebser, 524 U.S. at 290 ("Consequently, in cases like this one that do not involve official policy of the recipient entity, we hold that a damages remedy will not lie under Title IX unless an official who at a minimum has authority to address the alleged discrimination and to institute corrective measures on the recipient's behalf has actual knowledge of discrimination in the recipient's programs and fails adequately to respond.").

23. Congress does not have plenary power to regulate educational institutions, but it does have the power to appropriate federal funds. U.S. CONST. art. I, § 8. As an extension of this power, Congress routinely imposes conditions that obligate the recipients of such funding to comply with requirements that Congress would not necessarily have the power to impose directly. See, e.g., Pennhurst State Sch. \& Hosp. v. Halderman, 451 U.S. 1, 17 (1981) ("Unlike legislation enacted under $\S 5$, however, legislation enacted pursuant to the spending power is much in the nature of a contract: in return for federal funds, the States agree to comply with federally imposed conditions.").

24. See 20 U.S.C. $\S 1681$ (a) (2018).

25. See Davis, 526 U.S. at 641-42; Gebser, 524 U.S. at 290-91; Franklin, 503 U.S. at $74-75$.

26. Gebser, 524 U.S. at 288 (discussing that the regulatory scheme requires notice before imposing financial penalties). 
accidents or vicarious liability, intentional misconduct is entirely within the institution's power to prevent and control. ${ }^{27}$ Therefore, to ensure that the liability for damages does not sneak up on an unsuspecting funding recipient, the remedy only applies to cases involving intentional discrimination.

\section{B. Judicial Enforcement and the Deliberate Indifference Standard}

While money damages would appear to only apply in narrow cases, the Court has expanded situations where a funding recipient is deemed to intentionally discriminate. Significantly, in Gebser v. Lago Vista Independent School District, the Supreme Court held that an institution's deliberate indifference to a known violation of Title IX is a form of intentional discrimination that courts may remedy with money damages. ${ }^{28}$ Later, in Davis v. Monroe County Board of Education, the Supreme Court articulated the necessary elements that a plaintiff must establish in cases seeking money damages for student-on-student sexual harassment and assault. ${ }^{29}$ Under the Gebser/Davis standard, a plaintiff must prove that (1) an appropriate person, or someone with authority, had actual notice of sexual harassment or sexual assault; ${ }^{30}$ (2) notwithstanding such notice, the institution responded with deliberate indifference; and (3) the sexual harassment was "so severe, pervasive, and objectively offensive that it effectively bar[red] the victim's access to an educational opportunity or benefit." 31

This deliberate indifference standard has proven difficult for plaintiffs to satisfy for a number of reasons. First, the gold standard for actual notice is that institutional officials knew that the perpetrator of sexual misconduct

27. Id. at 290.

28. Id. at 290-93.

29. Davis, 526 U.S. at 642-45.

30. Later courts have clarified that the notice may address an incident that had occurred, was occurring, or was threatened. Williams v. Bd. of Regents of the Univ. Sys. of Ga., 477 F.3d 1282, 1293-94 (11th Cir. 2007); Escue v. N. Okla. Coll., 450 F.3d 1146, 1153 (10th Cir. 2006) (" $[\mathrm{H}]$ arassment of persons other than the plaintiff may provide the school with the requisite notice to impose liability under Title IX.”); Delgado v. Stegall, 367 F.3d 668, 672 (7th Cir. 2004) (internal citations omitted) (“'I]n Davis the Court required knowledge only of 'acts of sexual harassment' by the [harasser], not of previous acts directed against the particular plaintiff."), abrogated by Doe No. 55 v. Madison Metro. Sch. Dist., 897 F.3d 819 (7th Cir. 2018).

31. Davis, 526 U.S. at 633. 
had offended in an identical way in the past against the same victim. ${ }^{32}$ Prior misconduct by the same perpetrator that is less severe than the misconduct in the plaintiff's case will often fail to provide actual notice. ${ }^{33}$ In the same way, prior similar misconduct by the same perpetrator that is directed at a different victim ${ }^{34}$ or misconduct that is committed by someone other than the perpetrator may not be sufficient notice. ${ }^{35}$

Second, courts are reluctant to impose liability under the Gebser/Davis standard for sexual misconduct committed by someone other than a student or employee of the educational institution defendant. ${ }^{36}$ As with the other limitations of Gebser/Davis liability, the requirement that institutions have control over the harasser is rooted in fairness concerns that arise when compensatory damages are at issue. As a result, however, the threat of liability for damages provides little incentive to address even known threats posed by outsiders.

Third, the location of the misconduct can also make it more difficult for the plaintiff to satisfy the Gebser/Davis standard. This is especially true in cases where courts reject the idea that institutional liability could apply to misconduct that occurs between students in off-campus housing. ${ }^{37}$

32. See Catharine A. MacKinnon, In Their Hands: Restoring Institutional Liability for Sexual Harassment in Education, 125 YALE L.J. 2038, 2070 (2016).

33. Id. (citing Harden v. Rosie, 99 A.3d 950, 954-63 (Pa. 2014)).

34. Id. (citing Wills v. Brown Univ., 184 F.3d 20 (1st Cir. 1999)).

35. $I d$.

36. E.g., Hall v. Millersville Univ., 400 F. Supp. 3d 252, 289 (E.D. Pa. 2019) (reasoning that "educational institutions [are] on notice that they face potential liability for the misconduct of their students or other parties whom they play a critical role in connecting with the student" but not "a guest whom the university had no role in bringing to campus"); Samuelson v. Or. State Univ., 162 F. Supp. 3d 1123, 1134 (D. Or. 2016) (finding that the university "had no chance to vet" the harasser), aff'd, 725 F. App'x 598 (9th Cir. 2018). The University of Utah is being sued by parents of a student who was murdered in her dorm room by her boyfriend non-student. Hanna Knowles \& Marisa Iati, An Officer Allegedly Showed Explicit Photos of a Woman Later Killed by Her Ex-Boyfriend, WASH. Post (May 19, 2020, 7:34 AM CDT), https:/www.washingtonpost.com/education/2020/05/18/anofficer-allegedly-showed-off-explicit-photos-woman-later-killed-by-her-boyfriend/. The parents allege that the university had knowledge of the threat, but the University contends that they cannot be liable for damages under Title IX because the assailant was not a student. See Hall v. Millersville Univ., 400 F. Supp. 3d 252, 289-90 (E.D. Pa. 2019).

37. See Roe v. St. Louis Univ., 746 F.3d 874, 884 (8th Cir. 2014) ("The Supreme Court has made it clear, however, that to be liable for deliberate indifference under Title IX, a University must have had control over the situation in which the harassment or rape occurs.") (citing Davis v. Monroe Cty. Bd. of Educ., 526 U.S. 629, 645 (1999)); see also 
Finally, the Gebser/Davis standard defines deliberate indifference as a "clearly unreasonable" response to the threat it has received notice of. ${ }^{38}$ Consequently, this standard permits educational institutions to avoid liability in most cases. Even institutions that fail to respond at all to notice of a threat of sexual misconduct can sometimes avoid liability. For example, a university might not investigate a student's reported rape because it believed in good faith that investigative efforts would hinder law enforcement, ${ }^{39}$ or that the student's failure to file a formal complaint justified a lack of response. $^{40}$

Incomplete and impartial responses are even more likely to survive challenge. Even institutions whose responses violate their own policies, ${ }^{41}$ or

Hannah Brenner Johnson, Standing In Between Sexual Violence Victims and Access to Justice: The Limits of Title IX, 73 OKLA. L. ReV. 37 (2020).

38. MacKinnon, supra note 32, at 2066-67 (quoting Davis, 526 U.S. at 648); see also A.J. Bolan, Note, Deliberate Indifference: Why Universities Must Do More to Protect Students from Sexual Assault, 86 GEO. WASH. L. REV. 804, 816 n.71 (2018) (citing examples of cases that demonstrate the weakness of the deliberate indifference standard).

39. Moore v. Regents of the Univ. of Cal., No. 15-cv-05779-RS, 2016 WL 2961984, at *6 (N.D. Cal. May 23, 2016). Nonresponse does give rise to liability in other cases. See, e.g., Jennings v. Univ. of N.C., 482 F.3d 686, 700-01 (4th Cir. 2007) (holding that deliberate indifference could be satisfied by evidence that university official dismissed plaintiff's complaint about sexual harassment by her coach, telling her that that coach "was a 'great guy' and that she should work out her problems directly with him").

40. St. Louis Univ., 746 F.3d at 883; see also Ross v. Univ. of Tulsa, 180 F. Supp. 3d 951, 969 (N.D. Okla. 2016) ("Campus security officers and school administrators walk a fine line when they investigate a report of sexual assault by a victim who is unwilling to proceed or make any specific accusations. . . [The victim] only had one semester left of school and did not want any disruption of her life prior to her graduation. Interviewing [the victim's friend, the assaulter], and other members of the small [University of Tulsa] campus or ultimately taking action against [the assaulter] would undoubtedly have caused this type of unwanted disruption. While perhaps not in accordance with Title IX best practices or the OCR's guidance in the DCL, [the university's] response [to the victim's report] could not be deemed 'deliberately indifferent' in light of the nature of such report."), aff'd, 859 F.3d 1280 (10th Cir. 2017). But see Butters v. James Madison Univ., 145 F. Supp. 3d 610, 614, 621 (W.D. Va. 2015) (denying motion to dismiss where university justified its alleged failure to respond on complainant's unwillingness to file a formal complaint).

41. Facchetti v. Bridgewater Coll., 175 F. Supp. 3d 627, 637-39 (W.D. Va. 2016) (concluding that plaintiff did not sufficiently allege deliberate indifference even though her complaint alleged that the university violated its own policy by deterring her from reporting the matter to the police, failing to advise her of her rights, preventing her from presenting witnesses, and excluding her from information about the disciplinary process); Thomas v. Bd. of Trs. of the Neb. State Coll., No. 8:12-CV-412, 2015 WL 4546712, at *13-14 (D. Neb. July 28, 2015) (rejecting plaintiff's argument that university's failure to ensure that the 
violate policies promulgated by the Office for Civil Rights ${ }^{42}$ have avoided liability under the deliberate indifference standard.

\section{Deliberate Indifference as the New Regulatory Standard?}

Because deliberate indifference is the legal equivalent of intentional discrimination, the Gebser/Davis standard sets a low bar for institutions to clear in order to avoid liability. It is, by design, a much more permissive standard than regulators should use in their enforcement efforts. For many years, the Department of Education expressly acknowledged its authority to hold institutions to a higher standard than deliberate indifference. ${ }^{43}$ The Department requires institutions subject to Title IX to engage in a "prompt and effective" response to discrimination. ${ }^{44}$

In $1997,{ }^{45}$ and again in 2001, the Office for Civil Rights ("OCR"), which is the agency within the Department of Education that enforces civil rights laws prohibiting discrimination in schools, ${ }^{46}$ confirmed that this requirement applies to sexual harassment (a subset of sex discrimination, which is prohibited by Title IX).$^{47}$ OCR also confirmed that an institution's response must include "immediate and appropriate steps to investigate or otherwise determine what occurred." ${ }^{48}$ Those initial steps must then be

student accused of rape and murder completed sanctions for earlier acts of misconduct was deliberate indifference), aff'd, 667 F. App'x 560 (8th Cir. 2016) (per curiam).

42. Gebser v. Lago Vista Indep. Sch. Dist., 524 U.S. 274, 291-92 (1998); Karasek v. Regents of the Univ. of Cal., 956 F.3d 1093, 1107-09 (9th Cir. 2020). At best, courts consider noncompliance with the regulatory standard a factor to consider in the overall assessment of deliberate indifference. Butters v. James Madison Univ., 208 F. Supp. 3d 745, 757 (W.D. Va. 2016); Doe v. Forest Hills Sch. Dist., No. 1:13-CV-428, 2015 WL 9906260, at $* 9-10$ (W.D. Mich. Mar. 31, 2015).

43. See Office for Civil Rights, U.S. Dep't of Educ., Revised Sexual Harassment

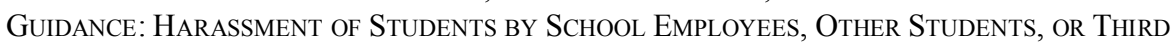
PARTIES iii-iv (2001), https:/www2.ed.gov/about/offices/list/ocr/docs/shguide.pdf [hereinafter 2001 Revised Sexual Harassment Guidance] (noting that the Gebser and Davis standards apply to private causes of action for monetary damages).

44. See id. at iii.

45. Sexual Harassment Guidance 1997, U.S. DeP'T OF EDUC., https://www2.ed.gov/ about/offices/list/ocr/docs/sexhar01.html (last visited June 1, 2020).

46. See About OCR, U.S. DEP'T OF EDUC., https://www2.ed.gov/about/offices/list/ocr/ aboutocr.html (last visited June 1, 2020).

47. 2001 ReVised SeXuAl Harassment Guidance, supra note 43, at 19-20 (noting that schools should "provid[e] . . . prompt and equitable resolution" to sexual harassment claims).

48. Id. at 15 . 
followed by "steps reasonably calculated to end any harassment, eliminate a hostile environment if one has been created, and prevent harassment from occurring again." 49 Furthermore, the school is "responsible for taking steps to remedy the effects of the harassment on the [affected] individual." ${ }^{50}$ OCR otherwise avoided imposing specific and uniform requirements on diverse educational institutions, instead preferring a "prompt and equitable" caseby-case evaluation that maximizes institutions' flexibility to create procedures best suited to their needs. ${ }^{51}$

In the wake of increased public attention to the problem of sexual assault on college campuses and lackluster responses by university officials, OCR offered further clarification in a Dear Colleague Letter released on April 4, 2011. ${ }^{52}$ This clarification aimed to end certain institutional practices, including the following:

- Improperly delegating investigation responsibilities to local law enforcement; ${ }^{53}$

- Imposing watered-down or no sanctions on responsible parties; ${ }^{54}$

- Discouraging victims from filing complaints-sometimes by pressuring them into informal mediation, excluding victims from disciplinary hearings; ${ }^{55}$

- Imposing an evidentiary standard that overprotects perpetrators; ${ }^{56}$

- Prohibiting victims from speaking about the matter $;^{57}$ and

- Failing to inform victims of investigation outcomes. ${ }^{58}$

Further, the Dear Colleague Letter required a university to investigate even when the alleged victim refused to file a complaint or actively participate in

49. $I d$.

50. Id.

51. Id. at 19-20.

52. Dear Colleague Letter, supra note 3.

53. Id. at $8 \mathrm{n} .23$.

54. See id. at 12-13.

55. Id. at 8 .

56. Id. at $9-12$.

57. $I d$. at 14 .

58. Id. at $13-14$. 
a disciplinary proceeding. ${ }^{59}$ Even though it is not appropriate to impose sanctions on an alleged perpetrator whose victim does not testify, the Dear Colleague Letter imposed a duty to respond to sexual assault that extended beyond efforts to identify and discipline the perpetrator. It also required universities to "pursue other steps to limit the effects of the alleged harassment and prevent its recurrence." 60 Such obligations include providing support and accommodations for the victim and engaging the community in prevention and training efforts. ${ }^{61}$

The current administration is changing course. First, the OCR withdrew the 2011 Dear Colleague Letter. ${ }^{62}$ Then, in November 2018, the Office proposed new regulations that incorporate the judicial deliberate indifference standard into its enforcement standard. ${ }^{63}$ It finalized these regulations in May 2020, ${ }^{64}$ codifying the deliberate indifference standard in a new provision, 34 C.F.R. 106.44(a):

A recipient with actual knowledge of sexual harassment in an education program or activity of the recipient against a person in the United States, must respond promptly in a manner that

59. Id. at 5 .

60. Id. The Letter also explains that in serious cases, an institution should not let the victim's request for confidentiality limit the university's response in ways that jeopardize the safety of the community. Id. at 5-6.

61. Id. at 5-6. Subsequent guidance clarified this point even further. See Office for Civil Rights, U.S. Dep't of Educ., Questions and Answers on Title IX and Sexual Violence 20 (Apr. 29, 2014), https://www2.ed.gov/about/offices/list/ocr/docs/qa-201404-title-ix.pdf ("Examples include providing increased monitoring, supervision, or security at locations or activities where the misconduct occurred; providing training and education materials for students and employees; changing and publicizing the school's policies on sexual violence; and conducting climate surveys regarding sexual violence. In instances affecting many students, an alleged perpetrator can be put on notice of allegations of harassing behavior and be counseled appropriately without revealing, even indirectly, the identity of the student complainant. A school must also take immediate action as necessary to protect the student while keeping the identity of the student confidential. These actions may include providing support services to the student and changing living arrangements or course schedules, assignments, or tests.").

62. Nondiscrimination on the Basis of Sex in Education Programs or Activities Receiving Federal Financial Assistance, 83 Fed. Reg. 61462, 61464-65 n.10 (proposed Nov. 29, 2018) (to be codified at 34 C.F.R. pt. 106).

63. Id. at 61466 .

64. Nondiscrimination on the Basis of Sex in Education Programs or Activities Receiving Federal Financial Assistance, 85 Fed. Reg. 30026, 30033-46, 30574 (final rule published May 19, 2020, effective Aug. 14, 2020) (codified at 34 C.F.R. 106.44(a)). 
is not deliberately indifferent. A recipient is deliberately indifferent only if its response to sexual harassment is clearly unreasonable in light of the known circumstances. ${ }^{65}$

The Department of Education has also diluted the notice standard that had previously been used in enforcement efforts. Whereas the prior administration required educational institutions to respond to sexual harassment that they "kn[ew] or reasonably should know about,"66 the new regulations adopt the judicial standard of actual knowledge in this regard, as well. ${ }^{67}$ This change reduces institutional accountability by ensuring that neither administrative enforcement nor judicial enforcement under the Gebser/Davis standard adequately pressures universities to address situations where the threat was not formally reported to university officials, even though they may have encountered information from which they reasonably should have understood that a threat existed or inquired further about this possibility. It may even provide incentive for university officials to avoid information that would give them actual knowledge of a threat. ${ }^{68}$

By unnecessarily adopting the Gebser/Davis standard for institutional liability, the new regulations therefore threaten to weaken Title IX's role in holding institutions accountable for responding to sexual misconduct committed by students, faculty, and staff. Because it is already difficult for victims to hold institutions accountable for mishandling Title IX adjudications, it is time to examine other theories of liability that might be brought to bear on educational institutions.

65. 34 C.F.R. 106.44(a) (2020).

66. Dear Colleague Letter, supra note 3, at 4; see also 2001 REviSED SEXUAL HARASSMENT GUIDANCE, supra note 43 , at iv.

67. See Nondiscrimination on the Basis of Sex in Education Programs or Activities Receiving Federal Assistance, 85 Fed. Reg. at 30089 (defining "actual knowledge" to mean "notice of sexual harassment or allegations of sexual harassment to a recipient's Title IX Coordinator or any official of the recipient who has the authority to institute corrective measures on behalf of the recipient").

68. See, e.g., American Association of University Professors, Comments on the Department of Education's Proposed Title IX Regulations 2 (Jan. 28, 2019), https:/www.aaup.org/sites/default/files/AAUP\%20title\%20IX\%20exec\%20summary_0.pdf; see generally Nancy Chi Cantalupo, Burying Our Heads in the Sand: Lack of Knowledge, Knowledge Avoidance, and the Persistent Problem of Campus Peer Sexual Violence, 43 LOY. U. CHI. L. J. 205 (2011). 


\section{Official Policy Liability}

Most sexual misconduct cases arising from the educational setting are litigated under the Gebser/Davis standard, which only imposes liability for an institution's indifferent response to the known acts of others. However, Title IX also imposes liability on educational institutions for their own, official discriminatory policies, custom, or pattern of practice. ${ }^{69}$ This theory of liability is so commonplace in Title IX cases-outside the sexual misconduct context - that it is rarely named or discussed outside of certain situations; for example, when a court must correct the mistaken belief that a university athletic department must have actual notice and respond with deliberate indifference to sex-based disparities in providing resources and opportunities. $^{70}$

In the context of sexual harassment, however, cases alleging discriminatory official policy are comparatively rare. Yet, it is clear that Gebser and Davis did not foreclose the application of official policy liability to the sexual harassment context. Simpson $v$. University of Colorado Boulder was the first case to apply official policy liability in this way. ${ }^{71}$ Though most lower courts that had an opportunity to consider official policy liability claims in the sexual harassment context rejected its application, the recent cases involving Tennessee and Baylor may be breathing new life into this doctrine.

\section{A. Official Policy Liability's Supreme Court Origins}

When the Supreme Court established the deliberate indifference standard in Gebser and Davis, it did not proffer that standard as the exclusive Title IX remedy for sexual harassment. While both cases utilized a deliberate indifference standard to assess institutional liability for sexual misconduct committed by a third party under its control, neither plaintiff alleged that the institution's indifference amounted to, or stemmed from, the

69. See infra Section IV.A.1.

70. See, e.g., Mansourian v. Regents of the Univ. of Cal., 602 F.3d 957, 969 (9th Cir. 2010) ("We therefore join the Fifth Circuit in holding that Gebser's notice requirement is inapplicable to cases alleging that a funding recipient has failed effectively to accommodate women's interest in athletics."); Pederson v. La. State Univ., 213 F.3d 858, 882 (5th Cir. 2000) ("In the instant case, it is the institution itself that is discriminating. The proper test is not whether it knew of or is responsible for the actions of others, but is whether Appellees intended to treat women differently on the basis of their sex by providing them unequal athletic opportunity ....").

71. 500 F.3d 1170 (10th Cir. 2007). 
university's own official policy. ${ }^{72}$ The Gebser Court expressly noted this distinction, limiting the applicability of the standard it employed to "cases like this one that do not involve official policy of the recipient entity." 73 This language created the possibility that, even in cases involving sexual harassment, institutions might be liable for their own discriminatory policy under a standard distinct from the Gebser/Davis standard.

Additionally, when crafting the Gebser/Davis standard, the Supreme Court supported the idea that deliberate indifference was tantamount to intentional discrimination when it analogized it to the standard for municipal liability under 42 U.S.C. $\S 1983$. Because the standard for municipal liability defines intentional discrimination to include both indifference to the discriminatory acts of employees and discriminatory policies and practices of the municipality itself, ${ }^{74}$ the Court's reference to municipal liability supports a parallel interpretation of intentional discrimination under Title IX, as well: incorporating both the education institution's deliberate indifference to acts of discrimination committed by its students or employees, as well as discriminatory official policies and practices of the educational institution itself. ${ }^{75}$

\section{$B$. Simpson v. University of Colorado Boulder}

In the 2007 case of Simpson v. University of Colorado Boulder, a federal appellate court examined official policy liability in a sexual harassment case for the first time. ${ }^{76}$ Here, the Tenth Circuit Court of Appeals reinstated two plaintiffs' claims that the university was liable for their sexual assaults, which were perpetrated by high school students on a recruiting visit hosted

72. See Davis v. Monroe Cty. Bd. of Educ., 526 U.S. 629, 644 (1999); Gebser v. Lago Vista Indep. Sch. Dist., 524 U.S. 274, 290-93 (1998).

73. Gebser, 524 U.S. at 290.

74. Id. at 291; see also 42 U.S.C. $§ 1983$ (2018). The Tenth Circuit in Simpson noted this connection as well. Simpson, 500 F.3d at 1178 ("[I]t is when execution of a government's policy or custom, whether made by its lawmakers or by those whose edicts or acts may fairly be said to represent official policy, inflicts the injury that the government as an entity is responsible under $\S 1983$.") (quoting Monell v. Dep’t of Soc. Servs. of N.Y., 436 U.S. 658, 694 (1978)).

75. For example, under the $\S 1983$ standard, a municipality may be held liable for discrimination inherent in its own staffing or training policy if the policy is obviously inadequate to protect likely violations of constitutional rights - such as arming police with weapons but failing to train officers on when the use of deadly force is legal. See Simpson, 500 F.3d at 1178-79 (discussing City of Canton v. Harris, 489 U.S. 378 (1989)).

76. Id. at 1184-85. 
by the University of Colorado football team. ${ }^{77}$ The university had arranged for female undergraduates to host the recruits and "show them a good time," which the recruits apparently understood to mean sex. ${ }^{78}$ Though the plaintiffs framed the case utilizing the typical Gebser/Davis framework, the court instead found the plaintiffs' evidence supported an alternative theory of liability. ${ }^{79}$

The court based this theory on the university's own discriminatory policy, which set up unsupervised high school football players with underclass female students with no clear instructions other than a general expectation to appeal and entertain. ${ }^{80}$ The court noted that the football program's failure to train or supervise the female students hired to host football recruits and "show them a good time" was deliberate indifference to an obvious risk, akin to a municipality that fails to train police officers on the proper deployment of firearms it provides. ${ }^{81}$ The risk of sexual misconduct in college football programs in general - and at the University of Colorado in particular - had been well-known for years and documented by research and media accounts. ${ }^{82}$ Numerous instances of sexual assault involving football recruits or the football program had occurred frequently enough in the past without athletic department officials intervening or addressing the program, despite the urging of law enforcement and others. ${ }^{83}$ Therefore, the court found that there was evidence that could establish a causal link between the university's official policy and the risk of sexual misconduct.

\section{Simpson in Contrast to the Gebser/Davis Deliberate Indifference Standard}

One way to understand how the Simpson standard differs from the Gebser/Davis standard is to contrast the appellate court's decision with the lower court's decision. The lower court in Simpson relied on the Gebser/Davis standard to dismiss the plaintiffs' claims. ${ }^{84}$ In doing so, the

77. Id. at 1173.

78. Id. at 1180 (quoting Appellant's App. Volume VII at 1343).

79. Id. at $1175-78$.

80. Id. at 1180 .

81. Id. at 1178-79 (citing City of Canton v. Harris, 489 U.S. 378, 390 n.10 (1989)).

82. Id. at 1181 .

83. Id.

84. Simpson v. Univ. of Colo., 372 F. Supp. 2d 1229, 1233-35 (D. Colo. 2005), rev'd, 500 F.3d 1170 (10th Cir. 2007). 
district court acknowledged that though Gebser/Davis liability is not limited to situations involving institutional indifference to a threat posed by precisely the same individual as the one who caused the harm, it does require that an institution ignore a "well-defined and focused" risk of harm. ${ }^{85}$ Though the head coach and other officials were aware of prior sexual misconduct committed by individuals involved in the football program, those prior instances were distinguishable from the harm that the plaintiffs faced. ${ }^{86}$ In those instances, either the sexual misconduct was committed by football recruits but not against current students, or the misconduct was committed against other students but by current players and not recruits. ${ }^{87}$ The Simpson plaintiffs could not prove that, prior to their sexual assaults, the head coach and other officials knew with certainty that recruiting events had included alcohol, strippers, and lap dances. ${ }^{88}$ As to what the officials did know, the court determined that they were not deliberately indifferent because they responded to the incident by disciplining the players involved. ${ }^{89}$

The analyses of the appellate and district courts in Simpson illustrate two key differences between Title IX liability under official policy liability and the Gebser/Davis standard. The first key difference is the extent to which courts may infer notice of discrimination. The notice requirement under the Gebser/Davis standard permits a narrower range of inferences from past events and discounts knowledge of general risks. ${ }^{90}$ In contrast, a university's official policy can be discriminatory if it fails to address a clear or obvious risk, where obviousness can be established by a wider range of information. ${ }^{91}$ The appellate court in Simpson did not limit its notice inquiry to the limited facts of the alleged sexual assault at issue - incidents between students and football recruits. Instead, the court considered what knowledge university and football officials generally had of sexual misconduct within its football program and other college football programs. ${ }^{92}$

85. Id. at 1236 .

86. Id. at $1238-40$.

87. Id.

88. Id. at $1240-42$.

89. Id. at $1244-45$.

90. See id. at 1236 ("In other words, the risk at issue must be well-defined and focused to support a claim of Title IX liability.").

91. See Simpson v. Univ. of Colo. Boulder, 500 F.3d 1170, 1178 (10th Cir. 2007).

92. Id. at $1180-85$. 
The second key difference is the role institutional policies play. The Gebser/Davis standard permits institutions to avoid liability by taking narrow, focused steps in response to the particular circumstances of known events. ${ }^{93}$ Consequently, an institution would rarely be faulted for failing to address systemic shortcomings with policy changes. But under official policy liability, institutional policies are much more important than narrow responses to prior events. In Simpson, the appellate court made clear that institutions can also be held responsible for indifference inherent in their policies. $^{94}$

In sum, Simpson v. University of Colorado Boulder confirms official policy liability as a distinct alternative to the Gebser/Davis deliberate indifference standard. It also illustrates how Title IX promotes institutional accountability for official decisions, as opposed to isolated instances of indifference, and for institutions' failure to address clear and obvious risks that would not necessarily satisfy the actual notice requirement.

\section{Official Policy Liability After Simpson}

Few judicial decisions address official policy claims in the context of sexual misconduct. Among the small subset of Title IX sexual misconduct cases that do include official policy claims, most produce decisions in which the court distinguishes Simpson and rejects the claim. Thus, recent decisions in which lower courts rejected motions to dismiss official policy claims against Baylor University and the University of Tennessee are noteworthy.

\section{Post-Simpson Official Policy Cases}

In decisions rejecting official policy claims, courts commonly distinguish Simpson on the grounds that the official policy in that case was one that affirmatively encouraged sexual misconduct. For example, a federal court in Kansas dismissed claims that a university's policy against investigating off-campus sexual violence constituted a discriminatory official policy under Title IX. "Unlike in Simpson," the court reasoned, the university "did not have an official policy that affirmatively encouraged students to engage in conduct off campus that could lead to sexual

93. See Simpson v. Univ. of Colo., 372 F. Supp. 2d 1229, 1235-37 (D. Colo. 2005), rev'd, 500 F.3d 1170 (10th Cir. 2007).

94. Simpson v. Univ. of Colo. Boulder, 500 F.3d 1170, 1178 (10th Cir. 2007).

95. Weckhorst v. Kan. State Univ., No. 16-CV-2255-JAR-GEB, 2017 WL 3674963, at *8 (D. Kan. Aug. 24, 2017). 
harassment or assault." ${ }^{, 96}$ Courts in other cases have also drawn similar distinctions, thus rejecting official policy liability. ${ }^{97}$

Similarly, absent allegations of a causal connection between an institution's policy and a threat of sexual assault, courts have rejected attempts to challenge training, grievance, or other policies. ${ }^{98}$ In one case, a federal court refused to dismiss challenges to Stony Brook University's grievance procedures because the university "had actual knowledge of a 'significant increase in reported sexual assaults at Stony Brook over the

96. $I d$.

97. See, e.g., K.S-A v. Haw., Dep't of Educ., Civ. No. 16-00115 ACK-KJM, 2018 WL 2144143, at*16 (D. Haw. May 9, 2018) ("Here, unlike in Simpson, there does not appear to be any evidence suggesting that Defendant created a situation which would encourage harassing conduct such that it needed to provide further training and policies to prevent such conduct from occurring."); Tackett v. Univ. of Kan., 234 F. Supp. 3d 1100, 1107 (D. Kan. 2017) ("Plaintiff attempts to graft Simpson liability by alleging KU required its female rowers to attend football games and cheer for the players as they entered the field, even if the rowers had been sexually assaulted by the players. Plaintiff also alleges that KU has an official policy and practice of entertaining football recruits in hotel just off campus and encouraging female KU athletes to attend parties with the recruits. But these alleged policies played no part in plaintiff's rape. Encouraging attendance and cheering at football games is not the equivalent of pairing female students with recruits to show them a good time.") (internal citations omitted); C.T. v. Liberal Sch. Dist., 562 F. Supp. 2d 1324, 1340 (D. Kan. 2008) ('Unlike CU's program of showing football recruits a 'good time' that was at issue in Simpson, a mere weight training program does not bear the element of encouragement of misconduct by the school district.").

98. See, e.g., Doherty v. Am. Int'l Coll., No. 17-CV-10161-IT, 2019 WL 1440399, at *6 (D. Mass. Mar. 31, 2019) (citing and contrasting Simpson in case where the plaintiff "has not shown how the identified training materials could lead a reasonable jury to conclude that AIC's training of the relevant officials was obviously deficient as to constitute a deliberate indifference to provide its Title IX administrators proper training"); Raihan v. George Washington Univ., 324 F. Supp. 3d 102, 109 (D.D.C. 2018) ("But 'the failure to promulgate a grievance procedure does not itself constitute "discrimination" under Title IX,' and neither does non-compliance with federal regulations.") (quoting Gebser v. Lago Vista Indep. Sch. Dist., 524 U.S. 274, 292 (1998)); Kollaritsch v. Mich. State Univ. Bd. of Trs., 298 F. Supp. 3d 1089, 1104-05 (W.D. Mich. 2017) (stating that "MSU's alleged failure to publish and distribute information about its sexual harassment policies and procedures" is distinguishable from the facts of Simpson because "[p]laintiffs here have not identified an official policy of MSU that created situations where sexual harassment or sexual assaults had occurred in the past, and where the risk had been ignored"); Doe v. Emerson Coll., 271 F. Supp. 3d 337, 356-57 (D. Mass. 2017) (concluding that Title IX only imposes liability for insufficient training policies where a school "sanctions a specific program that, without proper control, would encourage sexual harassment and abuse such that the need for training or guidance is obvious") (quoting C.T., 562 F. Supp. 2d at 1339). 
years." "99 The court further found that the deficiency of the university's responses to and policies regarding sexual assaults, which OCR had previously criticized, justified denying the defendant's motion to dismiss and permitting the plaintiff's claim of official policy discrimination to proceed. ${ }^{100}$ Also, in another case not involving official policy liability, the Eleventh Circuit held a school district liable under Title IX for its failure to improve its discipline, recordkeeping, and sexual harassment training following a student rape. ${ }^{101}$ In reaching this conclusion, the court reasoned that, had it been stronger, the sexual harassment training may have prevented the rape. ${ }^{102}$ Though most decisions have failed to apply official policy liability, two recent cases seem to buck this trend.

\section{Plaintiffs Successfully Allege Official Policy Claim Against the University of Tennessee}

In 2016, eight present and former female students sued the University of Tennessee. ${ }^{103}$ Seven plaintiffs ${ }^{104}$ alleged that they were sexually assaulted by male students affiliated with the football and basketball teams while enrolled at the university. ${ }^{105}$ Each plaintiff attributed their assault to institutional indifference to prior instances of misconduct known to university officials. ${ }^{106}$ Further, the plaintiffs alleged several specific policies had put them at risk of the sexual assault they ultimately experienced. ${ }^{107}$

The Tennessee district court found that the plaintiffs had alleged a prima facie case under the Gebser/Davis standard, and that they had sufficiently

99. Tubbs v. Stony Brook Univ., No. 15 Civ. 0517 (NSR), 2016 WL 8650463, at *9 (S.D.N.Y. Mar. 4, 2016).

100. Id.

101. Hill v. Cundiff, 797 F.3d 948, 973-75 (11th Cir. 2015).

102. Id. In this case, a staff member who was not sufficiently trained orchestrated a scheme to use the plaintiff as "bait" to catch a student who was threatening to sexually assault her. $I d$. at 973-74. The court considered these examples of post-assault policy inertia not on their own, but as part of an overall analysis of the school district's deliberate indifference under Gebser/Davis to the threat this perpetrator was known to pose. Id. 97375.

103. Doe v. Univ. of Tenn., 186 F. Supp. 3d 788, 791 (M.D. Tenn. 2016).

104. Id. The other plaintiff's alleged injury was retaliation for participating in an investigation into the sexual assault of her teammate and roommate, who was also one of the other plaintiffs. $I d$. at 800 . Such retaliation is actionable under Title IX but is outside the scope of this Article. See id. at 809.

105. Id. at 791 .

106. Id.

107. Id. at 791-92. 
alleged discriminatory official policies. ${ }^{108}$ Applying Gebser/Davis, the court found that the plaintiffs had "allege[d] far more than UT's knowledge of general risks or stereotypical assumptions[.]"109 According to the court, university officials had been "put on notice of a specific and concrete pattern of an 'inordinate' number of sexual assault allegations against members of specific [athletic] teams."

Concerning the plaintiffs' discriminatory official policy claims, the court accepted plaintiffs' allegations that the university promoted or sustained a culture that gave rise to the sexual violence they experienced. ${ }^{111}$ For example, the athletic department allegedly encouraged players to host "parties with underage drinking to benefit recruiting." 112 Further, the athletic department adopted as the football team's anthem the song "Turn Down for What," which the court noted to be "associated with "sexual violence and rape culture." "113 The department even went so far as to arrange for the song's creator, rapper Lil Jon, to make a guest appearance at a team event. ${ }^{114}$

The athletic department also failed to modify a housing policy that permitted female freshmen and upper-class male athletes to reside in the same dorm, even though the dorm served as the location for many of the plaintiffs' sexual assaults and prior assaults. ${ }^{115}$ Moreover, the court found that certain actions that the athletic department took allegedly helped foster a culture that encouraged sexual misconduct. ${ }^{116}$ Namely, the department had allegedly engaged in a pattern of covering up past instances of sexual misconduct committed by athletes; arranged for their legal representation;

108. Id. at $805-06$.

109. Id. at 807 .

110. Id.

111. Id. at $806-08$.

112. Id. at 793 (quoting the First Amended Complaint 23 (Docket No. 22)).

113. Id. (quoting the First Amended Complaint).

114. Id. (citing the First Amended Complaint qף 148-153).

115. See Complaint at 44, Doe v. Univ. of Tenn., 186 F. Supp. $3 d 788$ (M.D. Tenn. 2016) (No. 3:16-CV-199), 2016 WL 503310. In response to multiple alleged assaults in 2011, a university official unsuccessfully urged the athletic department and other university officials to address the rash of sexual assaults perpetrated by athletes, such as by changing the housing policies and ending their interference and influence over disciplinary process. $I d$. at 9-12.

116. Univ. of Tenn., 186 F. Supp. 3d at 806-08. 
interfered with and influenced the disciplinary process; and allowed athletes to avoid or delay discipline in order to complete their seasons. ${ }^{117}$

In addition, the plaintiffs alleged that the university and athletic department's response to their reports of sexual assault amounted to both deliberate indifference and discriminatory official policy. ${ }^{118}$ Specifically, the plaintiffs alleged that the university's intentional delay of proceedings, tolerance of harassment, lax enforcement procedures, and failure to conduct sufficient hearings amounted to both a deliberate indifference and discriminatory official policies. ${ }^{119}$

The plaintiffs sought damages and injunctive relief, but the university moved to dismiss the plaintiffs' claims. ${ }^{120}$ Accordingly, the court considered whether the allegations, if proven, could give rise to liability under Title IX. ${ }^{121}$ The court denied the motion. ${ }^{122}$ While the case settled before the litigation could proceed further, ${ }^{123}$ the court's preliminary ruling provides a touchstone for assessing the kinds of facts that, if true, could give rise to liability under Title IX under a theory of discriminatory official policy.

\section{Plaintiffs Successfully Allege Official Policy Liability Against Baylor University}

In another case, fifteen plaintiffs filed two separate lawsuits against Baylor University alleging that Baylor's discriminatory official policies and indifference to specific prior instances of assault led to each of them being sexually assaulted by another student. ${ }^{124}$ While some of the alleged assailants were members of the football team and other men's athletics

117. Id. at $793-94$.

118. Id. at 791-92.

119. Id. at 793-95.

120. Id. at 800 .

121. Id. at $804-08$.

122. Id. at 815-16. "The 'before' claims of Jane Does II-IV and VI-VIII will proceed, as will Jane Doe V's retaliation claim and the plaintiffs' claim for injunctive relief." Id. at 815.

123. Marie Andrusewicz, University of Tennessee Settles Sexual Assault Lawsuit, NPR: THE Two-WAY (July 6, 2016, 5:04 AM ET), https://www.npr.org/sections/thetwoway/2016/07/06/484891430/university-of-tennessee-settles-sexual-assault-lawsuit.

124. Doe 12 v. Baylor Univ., 336 F. Supp. 3d 763, 770-73 (W.D. Tex. 2018); Doe 1 v. Baylor Univ., 240 F. Supp. 3d 646, 653-56 (W.D. Tex. 2017). These cases were consolidated with each other, and with a case that has not yet produced any dispositive opinions, Jane Doe 11 v. Baylor Univ., No. 6:17-CV-228-RP. The consolidated case, No. 6:16-cv-173-RP, is currently pending in the U.S. District Court for the Western District of Texas. 
teams at Baylor, most were not student athletes. ${ }^{125}$ The plaintiffs alleged that Baylor University officials, including campus police and health services, took inadequate measures in response to their allegations of sexual assault. They claim that university officials misinformed victims about their rights under Title IX, provided inaccurate information about reporting options, discouraged them from reporting, failed to conduct investigations and disciplinary proceedings, withheld remedial measures, and failed to take steps to prevent campus encounters between the victims and their assailants. ${ }^{126}$ As a result, plaintiffs alleged, the absence of accountability allowed sexual misconduct to flourish. ${ }^{127}$

Moreover, during a time period when Baylor received multiple reports of sexual assault, the plaintiffs alleged that the university reported zero sexual assaults to the Department of Education. ${ }^{128}$ In doing so, the plaintiffs alleged that Baylor increased the risk of further sexual assault against the plaintiffs. ${ }^{129}$ Baylor moved to dismiss the suit, but, after determining that the plaintiffs had successfully alleged claims under both Gebser/Davis and official policy liability, the federal court denied Baylor's motion. ${ }^{130}$

The court rejected Baylor's argument that it lacked control over some of the alleged assaults that occurred off campus, suggesting that control is not a relevant consideration for official policy claims and rejecting the contention that universities lack control over events between students that occur in off-campus housing. ${ }^{131}$ Citing Supreme Court decisions that affirm the relationship between policy and custom, the court also rejected Baylor's argument that employees' conduct in implementing official policies should not count as evidence of those policies' content. ${ }^{132}$

In the wake of the court's decisions denying Baylor's motions to dismiss, the litigation has been in pre-trial discovery phase. But regardless whether the case proceeds to trial or settles, the court's recognition of the plaintiffs' official policy claims, like the decision against the University of Tennessee, helps illuminate the potential for official policy claims to promote institutional accountability, as examined in the next section.

125. See Doe 12, 336 F. Supp. 3d at 770-73; Doe 1, 240 F. Supp. 3d at 653-56.

126. Doe 12, 336 F. Supp. 3d at 770-73; Doe 1, 240 F. Supp. 3d at 653-56.

127. Doe 12, 336 F. Supp. 3d at 779-80; Doe 1, 240 F. Supp. 3d at 661-62.

128. Doe 12, 336 F. Supp. 3d at 773; Doe 1, 240 F. Supp. 3d at 662.

129. Doe 12, 336 F. Supp. 3d at 770-73; Doe 1, 240 F. Supp. 3d at 661-62.

130. Doe 12, 336 F. Supp. 3d at 779-83; Doe 1, 240 F. Supp. 3d at 661-62.

131. Doe 12, 336 F. Supp. 3d at 780-81.

132. Id. at $782-83$. 


\section{Tennessee and Baylor Decisions: Analysis and Opportunity}

Part III will underscore the Baylor and Tennessee decisions' expansive treatment of the elements of a Title IX claim for liability based on discriminatory official policy. It will then offer suggestions for application of the doctrine in an era of uncertain regulatory enforcement. Specifically, this Part highlights the deficiencies in deliberate indifference that are resolved through the application of official policy liability.

\section{A. Analysis of the Tennessee and Baylor Decisions}

After Simpson, a Title IX claim of discriminatory official policy must satisfy three elements: (1) there must be an "official" policy, custom, or pattern of practice; (2) the official policy must be discriminatory-either facially by intentionally treating students differently on the basis of sex, or inherently by demonstrating indifference to an obvious threat of sexual harassment; and (3) as the Baylor court emphasized, the policy must cause the harm in question by exposing the plaintiff to the risk of sexual harassment. ${ }^{133}$ The decisions refusing to dismiss official policy liability claims against Baylor and Tennessee apply these elements in a way that faithfully applies Simpson while maximizing the potential for the doctrine to hold institutions accountable. As such, a close examination of these recent cases may help breathe new life into the official policy doctrine.

\section{Official Policy}

Both decisions accepted the possibility that plaintiffs could prove that repeated actions by university officials could establish a university's "official" policy. ${ }^{134}$ The Baylor decisions addressed this issue most directly because Baylor had argued "that its written ... Title IX policy, and 'not employee violations of the policy,' constituted Baylor's official policy at

133. In one of its decisions, the district court in Baylor's case stated:

The Court remains sensitive to concerns that application of the official policy rubric to claims involving a school-wide risk of sexual assault may be taken to imply that higher education institutions, due to the prevalence of sexual assault among college-aged individuals, would face near-constant liability. . . . But the official-policy rubric's extension of liability is limited by its demand that plaintiffs demonstrate the misconduct complained of was "not simply misconduct that happened to occur [at the school] among its students," but was in fact caused by an official policy or custom of the university.

Id. at 780 (internal citation omitted) (quoting Simpson v. Univ. of Colo. Boulder, 500 F.3d 1170, 1174 (10th Cir. 2007)).

134. Doe 12, 336 F. Supp. 3d at 782; Doe 1, 240 F. Supp. 3d at 662. 
the time of the alleged assaults." $" 135$ The court rejected this argument, citing Simpson and Gebser's analogy to municipal liability under 42 U.S.C. $\S$ 1983, which applies to both policy and custom. ${ }^{136}$ Accordingly, to survive a motion to dismiss, the plaintiffs' allegations need only establish that the institution's "practice of inadequately handling and even discouraging reports of peer sexual assault constituted an official policy." 137

\section{Discriminatory Policy}

The Simpson court explained that an institution's official policy can be intentionally discriminatory if the institution retains the policy in the face of evidence that that the policy increases the risk that students will endure sexual misconduct. ${ }^{138}$ Because of the nature of the policy and the threat at issue in Simpson, the Tenth Circuit examined whether the athletic department knew about rampant sexual assault in college football in general. ${ }^{139}$ Equally important, however, was whether the department knew about past sexual misconduct that, while not identical to the facts in Simpson, occurred within the university's football program. ${ }^{140}$ In light of university officials' knowledge, the policy of allowing unsupervised football recruiting visits and encouraging hosts to indulge the recruits was indifferent to the known risk and thus intentionally discriminatory. ${ }^{141}$

The Baylor and Tennessee courts also accepted plaintiffs' arguments that an institutional policy could intentionally discriminate by expressing indifference to a known threat. ${ }^{142}$ But the courts' analysis in each case suggests that specific allegations of who knew what about which past assaults is not essential for official policy claims, despite the Simpson court focusing on those issues. ${ }^{143}$

135. Doe 12, 336 F. Supp. 3d at 782 (quoting Def.'s Motion to Dismiss Doe 12, Docket No. 20, at 8; Def.'s Motion to Dismiss Doe 14, Docket No. 22, at 7-10; Def.'s Motion to Dismiss Doe 15, Docket No. 23, at 8-9).

136. Id.

137. Id.

138. See Simpson, 500 F.3d at 1178.

139. Id. at 1181 .

140. Id. at $1180-82$.

141. Id. at 1184-85.

142. Doe 12, 336 F. Supp. 3d at 781-83; Doe 1 v. Baylor Univ., 240 F. Supp. 3d 646, 660-61 (W.D. Tex. 2017); Doe v. Univ. of Tenn., 186 F. Supp. 3d 788, 806 (M.D. Tenn. 2016).

143. Compare Simpson, 500 F.3d at 1176 (discussing the importance of actual knowledge in Title IX official policy claims), with Doe 12, 336 F. Supp. 3d at 779 (holding 
In Tennessee, the court highlighted allegations that described the university's indifference as a failure to amend its policies and practices despite a pattern of sexual assault incidents involving athletes and criticism from numerous university officials. ${ }^{144}$ Those officials included university personnel outside athletics, others within athletics, and the former vicechancellor of the university. ${ }^{145}$ Each official raised concerns about the athletic department's interference with disciplinary proceedings, continued practice of co-housing female freshmen and upper-class male athletes, refusal to train athletes about sexual assault, and replacement of female staff and administrators with male employees. ${ }^{146}$ Notably, the court did not compare the facts of those incidents to those that the plaintiff experienced. ${ }^{147}$ By declining to do so, the Tennessee court emphasized that the proper inquiry in an official policy claim is whether the university had general knowledge — rather than actual knowledge — of a specific threat. ${ }^{148}$

Baylor's alleged indifference was even more apparent on the face of the practices of its staff-tantamount to policies - in obstructing the plaintiffs from reporting, handling investigations inadequately, and misreporting sexual assault incidents. ${ }^{149}$ In Baylor, the court did not require the plaintiffs to allege that university officials were aware of the impact that these deficiencies had on specific incidents of sexual assault or campus sexual assault in general; instead, the court allowed the obvious correlation/connection to speak for itself. ${ }^{150}$ While not requiring the plaintiffs to prove university official knowledge of the activities, plaintiffs are still bound to show causation between these practices and the misconduct they experienced.

\section{Causation}

The most notable aspect of the Tennessee and Baylor decisions is the way the federal courts treated the element of causation. In Simpson, that

\footnotetext{
that actual notice is not required where a Title IX violation is caused by official policy), and Doe 1, 240 F. Supp. 3d at 661 (explaining that actual notice is not required in official policy cases), and Univ. of Tenn., 186 F. Supp. 3d at 805 (rejecting argument that actual knowledge is required for official policy claims).

144. Univ. of Tenn., 186 F. Supp. 3d at 793-94, 806-07.

145. Id. at 793-94.

146. Id.

147. See id.

148. Id. at 807-08.

149. See Doe 12 v. Baylor Univ., 336 F. Supp. 3d 763, 782-83 (W.D. Tex. 2018).

150. See id.
} 
court found causation where the university created and administered the football recruiting program in a way that directly provided the plaintiffs' assailants with access and opportunity to commit sexual assault. ${ }^{151}$ In contrast, Tennessee's discriminatory official policies were alleged to have infected the culture of the entire athletic department-not just the football program. ${ }^{152}$ And Baylor's policies were not even confined to the athletic department, but allegedly affected the university campus as a whole. ${ }^{153}$

In this way, the Tennessee and Baylor decisions depart from other cases that distinguish Simpson on the grounds that the allegedly discriminatory official policy was not targeted at a specific program, such as "football recruiting." 154 For example, a federal district court in Massachusetts declined to hold a university liable for its allegedly insufficient training policies by reading Simpson to require a "specific program" giving rise to the threat of sexual harassment or abuse. ${ }^{155}$ But as the Baylor and Tennessee courts read Simpson, it is not essential that the allegedly discriminatory policy operate within a specific university program that gave rise to threat of harassment.

Additionally, as noted above, ${ }^{156}$ some lower court decisions have read Simpson to mandate that the policy in question created the threat by providing "affirmative encouragement," such as by pairing high school males with freshman female hosts who have been trained and instructed only to try to show the recruits a good time. ${ }^{157}$ These decisions have allowed allegations to proceed because a failure to hold earlier offender accountable could evidence the policy's active role in creating the threat. ${ }^{158}$ A university's policies can play an active role in elevating the threat of sexual assault or misconduct by directly causing the conduct at issue, or through more remote causes. ${ }^{159}$

In Tennessee, the athletic department's policy and custom of helping athletes avoid punishment demonstrated institutional tolerance for sexual

151. Simpson v. Univ. of Colo. Boulder, 500 F.3d 1170, 1184-85 (10th Cir. 2007).

152. Univ. of Tenn., 186 F. Supp. 3d at 807.

153. See Doe 12, 336 F. Supp. 3d at 769-70; Doe 1 v. Baylor Univ., 240 F. Supp. 3d 646, 654-56 (W.D. Tex. 2017).

154. See supra notes $76-83$ and accompanying text.

155. Doe v. Emerson Coll., 271 F. Supp. 3d 337, 356-57 (D. Mass. 2017).

156. See supra notes $77-85$ and accompanying text.

157. Weckhorst v. Kan. State Univ., No. 16-CV-2255-JAR-GEB, 2017 WL 3674963, at *8 (D. Kan. Aug. 24, 2017).

158. See id.

159. See supra notes $139-43$ and accompanying text. 
misconduct. ${ }^{160}$ Consequently, those policies motivated or inspired offenders who might otherwise have been deterred had they believed the athletic department would hold them accountable. ${ }^{161}$

In Baylor, the court emphasized that causation is essential and the only thing protecting institutions from "near-constant liability" whenever a student is raped. ${ }^{162}$ But, at the same time, the court accepted as sufficient a causal link between policies that deter reporting and the increased likelihood of students experiencing sexual misconduct, without even discussing whether the assailants that evaded reporting are specifically alleged to be the same assailants that assaulted plaintiffs in the case. ${ }^{163}$ In other words, the Baylor court accepted a version of the "culture of tolerance" theory that the Tennessee court applied-though in the context of an entire campus, rather than just the athletic department. ${ }^{164}$

The Baylor court implicitly addressed one final aspect of causation during its examination of the issue of control. Under the Gebser/Davis

160. See Doe v. Univ. of Tenn., 186 F. Supp. 3d 788, 794-800, 806 (M.D. Tenn. 2016).

161. To be sure, Tennessee was alleged to have actively contributed to the culture by endorsing the football team's appreciation for rap music. Id. at 793. But it's hard to imagine that any court interpreting Simpson to require such an active role as the role as the University of Colorado played in constructing the environment for sexual assault would have found the rap music nexus to be sufficient. Instead, the allegations about Tennessee's athletic department's unofficial policy of failing to discipline athletes seems was arguably the stronger contribution to the elevated risk of sexual misconduct that the plaintiffs in that case alleged.

162. Doe 12 v. Baylor Univ., 336 F. Supp. 3d 763, 780 (W.D. Tex. 2018).

163. See id. at 782 .

164. Id. ("Plaintiffs allege that Baylor, 'its staff, and highest officers,' with knowledge of numerous and detailed reports of sexual assault, 'maintained a set of policies, procedures, and customs ... that were implemented in a sexually discriminatory manner,' and 'permitted a campus condition rife with sexual assault,' that 'substantially increased Plaintiffs' chances of being sexually assaulted."') (internal citations omitted) (quoting the Amended Complaint (Docket No. 14)). The court then went on to provide specific examples of the policies alleged to be deficient, but did not articulate specific connections between the policies and the "campus condition," or the "campus condition" and the specific threat to the plaintiffsallowing these obvious connections to speak for themselves. See id. at 782-83.

While this Article was in production, the Ninth Circuit Court of Appeals made a similar observation about causation, reinstating plaintiff's claim that a university's policy of overreliance on informal resolution caused the sexual assault. The court rejected the University's argument that Simpson requires a program-specific theory of causation. Karasek v. Regents of the Univ. of Cal., 996 F.3d 1093, 1113 (9th Cir. 2020) ("But we will not foreclose the possibility that a plaintiff could adequately allege causation even when a school's policy of deliberate indifference extends to sexual misconduct occurring across campus."). 
standard, plaintiffs must allege specific facts that establish institutional control over the assailant. ${ }^{165}$ Such controls exist either because the assailant is a student or employee, or because the location or context where the assault occurred was under institutional control. ${ }^{166}$ Baylor attempted to import this requirement to an official policy claim by arguing that the plaintiffs did not include allegations that the university had control over the assailants. ${ }^{167}$ The court, nonetheless, found the plaintiffs' allegations "that Baylor's disciplinary measures were inadequate and intentionally discriminatory, causing a heightened risk of sexual assault for Baylor students" sufficient to evidence control. ${ }^{168}$ The court's discussion demonstrates that the Gebser/Davis inquiry into institutional control over the assailant is not relevant in an official policy claim. ${ }^{169}$ Instead, it is subsumed by the element of causation: a policy that is not discriminatory or indifferent will have materially reduced the risk of sexual assault that the plaintiff faced.

In sum, the Baylor and Tennessee decisions illustrate the potential breadth of official policy liability by illustrating: that policy need not be written but proven based on the conduct of university employees; that intentional discrimination includes indifference to a threat that is generally understood rather than specifically predicted by past events; that the causation inquiry is not limited to whether universities have actively and directly caused the risk of sexual misconduct, but can also be satisfied by a showing that the university's policy demonstrated tolerance for sexual misconduct within a program or within the campus as a whole; and that the requirement for institutional control over the assailant is not a separate requirement for liability, but part of the inquiry as to whether university policy has the power to minimize the risk of sexual misconduct that the plaintiff experienced.

\section{B. Potential Applications}

Under the new regulations, the Department of Education will limit enforcement to situations that would qualify for money damages under the

165. Davis v. Monroe Cty. Bd. of Educ., 526 U.S. 629, 644-46 (1999); Gebser v. Lago Vista Indep. Sch. Dist., 524 U.S. 274, 290 (1998).

166. Davis, 526 U.S. at 644.

167. Doe 12, 336 F. Supp. 3d at 781.

168. Id.

169. Id. at $781-83$. 
Gebser/Davis standard. ${ }^{170}$ As previously noted, such a change is unnecessary and unwarranted by the absence of particular fairness and notice issues that exist when the courts are evaluating claims for money damages by individuals who are essentially third-party beneficiaries to an agreement between the government and the institution that conditions federal funding on Title IX compliance. ${ }^{171}$ Lowering the regulatory standard would likely lead to underenforcement of Title IX. It would essentially render both courts and OCR powerless to hold institutions accountable for sexual misconduct that does not involve the narrow range of facts that would satisfy Gebser/Davis.

Thus, it is particularly helpful to consider alternatives to Gebser/Davis liability. Official policy liability, as first used in Simpson and then expansively construed in the Baylor and Tennessee cases, will help ensure that Title IX continues to impose accountability on educational institutions for their policies and practices regulating sexual misconduct. Specifically, this theory of liability addresses three deficiencies in the Gebser/Davis theory of liability: first-time perpetrators, off-campus assaults and nonstudent perpetrators, and injunction-only cases.

\section{First-Time Perpetrators}

Gebser/Davis liability is difficult to establish in cases where the institution had no notice of the threat posed by the alleged perpetrator. Generally, in such cases, the perpetrator had not offended previously or had engaged in less serious behavior than the offense for which the plaintiff is seeking damages. Simpson itself demonstrates the expansive potential here, as the court concluded that liability for failing to reform its policies in response to knowledge that the football recruiting program in general creates a risk of sexual assault, not a risk posted by the specific recruits who assaulted the plaintiffs in that case. ${ }^{172}$

\section{Off-Campus Assaults and Non-student Perpetrators}

Off-campus sexual assaults and assaults committed by non-student perpetrators are weak candidates for Gebser/Davis liability due to the requirement that institutions have control over the sexual assault for liability to apply. But as the Baylor court explained, an official policy claim does not look at whether the school had control; rather, courts will look at

170. See supra notes 63-69 and accompanying text.

171. See supra notes 16-26 and accompanying text.

172. See supra note 86 and accompanying text. 
whether the policies or customs of the university "caus[ed] a heightened risk of sexual assault" for the university's students. ${ }^{173}$ As such, official policy liability may be proper in cases where an institution successfully defends itself under Gebser/Davis based on a lack of control over the sexual assault.

To illustrate, imagine a university whose campus security has a policy or practice of failing to intervene in cases where students report an on-campus threat posed by individuals who are not affiliated with the university. ${ }^{174}$ Imagine further that a student calls campus security to report that her estranged partner, who is not a student, has come to campus and threatened her; according to the student, his return is imminent. Consistent with their policy or custom, the campus police do not intervene, and the estranged partner commits an act of sexual violence that is within the scope of Title IX.

Such a case would likely fall outside the scope of Gebser/Davis on the grounds that that the university lacks control over the perpetrator. ${ }^{175}$ But the causal nexus between the policy and the increased threat is apparent. The university's policy has increased the risk to the student of enduring violence that is protected under Title IX. Moreover, due to the student's reports, the threat is undeniably "obvious" in a way that many or even most non-student perpetrators would not necessarily be.

\section{Injunction and Injunction-Only Cases}

Beyond the ability of plaintiffs to seek damages from universities, official policy claims premised on deficient policy or custom are good candidates for injunctive relief. Policies involving an institution's training, supervision, and disciplinary responses are all potential targets for injunctive relief for a successful claim for official policy liability. For example, the Tennessee court allowed the plaintiffs' action to move forward on its claims for injunctive relief regarding the university's failure to discipline drinking, drug use, and sexual assault, as well as the university's endorsement of inappropriate parties and biased implementation of

173. Doe 12, 336 F. Supp. 3d at 781.

174. The hypothetical is based on McCluskey v. Utah. Complaint at 41, McCluskey v. Utah, No. 2:19-cv-00449-HCN (D. Utah June 27, 2019).

175. See, e.g., Hall v. Millersville Univ., 400 F. Supp. 3d 252, 287-89 (E.D. Pa. 2019); Karasek v. Regents of the Univ. of Cal., No. 3:15-CV-03717-WHO, 2018 WL 1763289, at *12 (N.D. Cal. Apr. 12, 2018); Samuelson v. Or. State Univ., 162 F. Supp. 3d 1123, 1126 (D. Or. 2016), aff'd, 725 F. App'x 598 (9th Cir. 2018). 
disciplinary proceedings. ${ }^{176}$ The availability of judicial relief through official policy liability to address these kinds of policy deficiencies is particularly fitting in the wake of a new Gebser/Davis standard for regulatory action, which could weaken the government's oversight over such matters.

One thing that could threaten the power of official policy liability to enhance institutional accountability on matters of sexual misconduct is the requirement that plaintiffs have standing to pursue the injunctive relief in the form of prospective policy change. This is not a concern in administrative enforcement, since standing is not required to initiate an administrative complaint under Title IX ${ }^{177}$ Nor is it a problem for plaintiffs bringing Gebser/Davis claims, as such claims allow plaintiffs to pursue compensatory damages for injury that has already occurred. ${ }^{178}$

However, the Tennessee case provides an example of plaintiffs surmounting this obstacle. There, the court rejected the university's argument that plaintiffs who had already graduated lacked standing to pursue administrative relief. ${ }^{179}$ The university had cited the Eleventh Circuit's decision in Williams v. University of Georgia for its argument. ${ }^{180}$ In Williams, the plaintiff prevailed under the Gebser/Davis standard on her claim for money damages stemming from a rape orchestrated by a studentathlete whose coach had allowed him to transfer into the school, despite the athlete's sexual misconduct at two prior schools. ${ }^{181}$ Though the plaintiff

176. Doe v. Univ. of Tenn., 186 F. Supp. 3d 788, 812-14 (M.D. Tenn. 2016).

177. Diane Heckman, Jackson v. Birmingham Board of Education: Supreme Court to Review Whether There is a Title IX Cause of Action by an Athletic Department Employee for Retaliation, 194 ED. L. REP. 1, 15 (2005) (noting that the Office of Civil Rights has "allowed individuals to file Title IX administrative complaints on behalf of student-athletes, regardless of whether that individual would have judicial legal standing, and would accept confidential filings").

178. See, e.g., City of Los Angeles v. Lyons, 461 U.S. 95, 105 (1983) (differentiating between standing to pursue compensatory damages for past harm, which was assumed, and standing to pursue injunctive relief).

179. Univ. of Tenn., 186 F. Supp. 3d at 813 ("The court is, however, persuaded by the plaintiffs' argument that, even if all of the Jane Does have permanently withdrawn from UT, they may still have standing to pursue their claim for injunctive relief as relates to UT's postassault practices, based on the fact that at least some of them are still involved in ongoing proceedings (either disciplinary proceedings against their assailants or proceedings challenging decisions about their own academic standing).").

180. Id. at 814 .

181. Williams v. Bd. of Regents of the Univ. Sys. of Ga., 477 F.3d 1282, 1290 (11th Cir. 2007). 
prevailed under the deliberate indifference standard, the court rejected her claim for injunctive relief because neither she nor the assailant were still students. ${ }^{182}$

Despite the apparent similarities, the Tennessee court distinguished Williams. ${ }^{183}$ First, it noted that, unlike the students in Williams, some of the plaintiffs in the Tennessee case were still students at the time of litigation. ${ }^{184}$ Moreover, their claims alleged a widespread pattern of Title IX violations beyond the particulars of the plaintiffs' cases, dissimilar to the Williams case. ${ }^{185}$ The court found that even if none of the plaintiffs were still enrolled students, they would still have standing to pursue injunctive relief against the university's disciplinary policies and customs. ${ }^{186}$ For example, some of the plaintiffs were still involved with those disciplinary proceedings, and some "felt forced to leave school because their assailants ha[d] not been adequately disciplined" but wished to return to the school if the injunctive relief was granted. ${ }^{187}$ This analysis demonstrates that standing, while challenging to prove for student plaintiffs seeking injunctive relief, is not an insurmountable obstacle. Therefore, while standing must be strategically considered by attorneys while drafting complaints, the doctrine does not necessarily undermine the viability of an accountability strategy built on official policy liability claims.

In fact, the Tennessee court's analysis of standing within the context of an official policy claim raises the question of whether a student would even need to be sexually assaulted to challenge deficient policies and practices if they are only pursuing injunctive relief, instead of pursuing both injunctive relief and money damages. If the plaintiff in such a case could prove that a university's policy or practice heightened the risk of sexual assault because it was deficient in the face of an obvious risk, why would a sexual assault actually need to occur? Any plaintiff who experiences that heightened risk could arguably allege an injury sufficient to satisfy the standing requirement. If this interpretation is true, special interest groups could possibly seek to litigate changes to university policies that might result from the Department of Education's anticipated weakening of the regulatory standard.

182. Id. at $1299,1303$.

183. Univ. of Tenn., 186 F. Supp. $3 \mathrm{~d}$ at 814.

184. Id. at $813-14$.

185. Id. at 814 .

186. Id. at 813 .

187. Id. 


\section{Conclusion}

Though most Title IX cases challenge institutional responses to sexual misconduct under the Gebser/Davis framework, another theory of liability aimed at challenging discriminatory official policy already exists and has precedent in sexual misconduct cases. As evidenced by two recent decisions in cases involving sexual misconduct at the University of Tennessee and Baylor University, there is potential for a more expansive interpretation of this theory than courts have generally rendered to this point. Whether it leads to judicial remedy or merely increases pressure on schools to settle, official policy liability possesses untapped potential for leveraging Title IX to hold educational institutions accountable for instances of sexual assault and misconduct. Given that institutions may have less to fear from the government's enforcement after new regulatory changes take effect, the time is ripe to raise the profile of Title IX's theory of official policy liability. 